\title{
Structure and integrity of fish assemblages in streams associated to conservation units in Central Brazil
}

\author{
Thiago Belisário d'Araújo Couto ${ }^{1}$ and Pedro De Podestà Uchôa de Aquino²
}

This study aims to characterize the spatial and seasonal distribution of the fish assemblage and evaluate the integrity of streams in a sustainable use area that includes integral protection conservation units in Distrito Federal, Central Brazil (Cerrado biome). For the study, 12 stretches of 8 streams were sampled in 2008 (dry season) and 2009 (wet season). For that evaluation was estimated the Physical Habitat Index (PHI), vegetation cover (VC), pH, dissolved oxygen, turbidity, and conductivity. We recorded 22 species, about eight undescribed species, by a total of 2,327 individuals. The most representative families in number of species were Characidae (31.8\%), Loricariidae (31.8\%), and Crenuchidae (13.6\%). Knodus moenkhausii was the most abundant species with 1,476 individuals, added to Astyanax sp., Phalloceros harpagos, and Hasemania sp. they represent over 95\% of the total abundance. The species Astyanax sp. (occurring in $79.2 \%$ of the stretches) and K. moenkhausii $(50.0 \%)$ were considered constant in both seasons. The longitudinal gradient (River Continuum) exerts a strong influence on the studied assemblage. According to CCA, the variables that structure the fish assemblage are based on aspects related to water volume and habitat complexity. No seasonal variation in richness, diversity, abundance, and mass were detected. A cluster analysis suggests a separation of species composition between the stretches of higher and lower orders, which was not

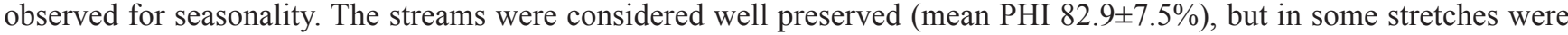
observed anthropogenic influence, detected in the water quality and, mainly, on the riparian vegetation integrity. The exotic species Poecilia reticulata was sampled in the two stretches considered most affected by anthropogenic activities by PHI, conductivity, and VC.

Esse estudo teve como objetivo caracterizar a distribuição espacial e sazonal da taxocenose de peixes e avaliar a integridade dos córregos de uma área de uso sustentável que inclui unidades de conservação de proteção integral no Distrito Federal, Brasil Central (bioma Cerrado). Para o estudo, foram amostrados 12 trechos de oito cursos d'água em 2008 (estação seca) e 2009 (estação chuvosa). Para essa avaliação foram utilizados o Índice Físico do Habitat (IFH), cobertura vegetal (CV), pH, oxigênio dissolvido, turbidez e condutividade. Foram coletadas 22 espécies, sendo oito não descritas, em um total de 2.327 indivíduos. As famílias mais representativas em número de espécies foram Characidae (31,8\%), Loricariidae (31,8\%) e Crenuchidae (13,6\%). Knodus moenkhausii foi a espécie mais abundante, com 1.476 indivíduos, que juntamente com Astyanax sp., Phalloceros harpagos e Hasemania sp. representaram mais de $95 \%$ da abundância total. As espécies Astyanax sp. (ocorrendo em 79,2\% dos trechos) e K. moenkhausii (50,0\%) foram consideradas constantes nas duas estações. O gradiente longitudinal (rio Contínuo) exerce forte influência na taxocenose estudada. De acordo com a CCA, as variáveis que estruturam a taxocenose íctica se baseiam em aspectos relacionados ao volume e complexidade dos habitats. Não foi detectada variação sazonal na riqueza, diversidade, abundância e massa. Uma análise de agrupamento sugere uma separação na composição de espécies entre trechos de maiores e menores ordens, o que não foi observado para a sazonalidade. Os córregos da APA encontram-se relativamente bem preservados (IFH médio de $82,9 \pm 7,5 \%$ ), porém em alguns trechos foi observada certa influência antrópica, detectada na qualidade da água e, principalmente, na integridade da vegetação ripária. A espécie exótica Poecilia reticulata foi coletada nos dois trechos considerados mais afetados por atividades antrópicas de acordo com o IFH, condutividade e CV.

Key words: Cerrado, Habitat quality, Headwaters, Upper Paraná river.

\footnotetext{
'Laboratório de Limnologia, Departamento de Ecologia, Instituto de Ciências Biológicas, Universidade de Brasília (UnB). Câmpus Darcy Ribeiro, 70910-900 Brasília, DF, Brazil. couto.thiagoba@gmail.com

${ }^{2}$ Departamento de Zoologia, Instituto de Ciências Biológicas, Universidade de Brasília (UnB). Câmpus Darcy Ribeiro, 70910-900 Brasília, DF, Brazil.pedropua@gmail.com
} 


\section{Introduction}

Fishes of small size streams exhibit strong dependence of structural characteristics of the environment (Gorman \& Karr, 1978; Poff, 1997). Its distribution is influenced by hydrogeological variables in detriment to biological interactions (Peres-Neto, 2004). In headwaters streams, as a result of shading caused by riparian vegetation, the primary production is usually extremely deficient, unlike larger rivers, where is possible the establishment of algae and macrophytes in larger proportion (Vannote et al., 1980). Consequently, the ichthyofauna of these systems, as well as the whole community, are extremely dependent of allochthonous input from the riparian vegetation (e.g., leaves, twigs, flowers, fruits, and terrestrial arthropods that fall into the water) to feed, shelter and reproduce (LoweMcConnell, 1987; Castro, 1999). Castro (1999) emphasizes the small size as a general pattern of headwaters fish fauna. Among other things, this pattern exists due the low productivity of these systems (Vannote et al., 1980) and the small size prey that compose their diets (Castro, 1999).

As a result of human actions, the headwater streams ichthyofauna is suffering strong pressure, mainly by the indiscriminate use of pesticides, construction of dams, deforestation and changes in riparian vegetation, introduction of exotic species and siltation (Castro \& Menezes, 1998; Casatti et al., 2006b). The Paraná basin, also characterized by having intense agricultural activity, contains the areas with the highest population densities and the most industrialized region of Brazil (Agostinho et al., 2007). Because of the high diversity and the threats resulted by agricultural expansion, the Brazilian Savanna (Cerrado) is rated as one of 25 global hotspots. Estimates predict that there is only 20\% of the original biome preserved, with only $6.2 \%$ destined to conservation areas (Myers et al., 2000), some of them classified as of sustainable use. In this case, human occupation, presence of private lands, and extractivism are allowed (Sistema Nacional de Unidades de Conservação SNUC, Law 9985/00).

The Brazilian fish fauna stands out for its richness and diversity. Currently, there are 2,587 species described for freshwater ecosystems, representing about $55 \%$ of freshwater fish species of the Neotropical Region (Buckup et al., 2007). According to Langeani et al. (2007), 310 fish species are recorded for upper Paraná, in which 236 (76.1\%) are considered native (autochthonous), 67 (21.6\%) are species introduced from other basins of the Neotropical Region (allochthonous) and seven $(2.3 \%)$ are exotic from other continents. About $65 \%$ of these species are small sized $(\leq 21 \mathrm{~cm})$ and most of them occur exclusively in headwaters streams (Langeani et al., 2007).

According to Aquino et al. (2009), despite of recent efforts, the Center-West region of Brazil still faces a shortage of data involving fish assemblages in streams of upper Paraná. Is worthwhile to mention some studies conducted in the States of Goiás (Benedito-Cecilio et al., 2004; Fialho et al., 2007; Araújo \& Tejerina-Garro, 2007) and Mato Grosso do Sul (Súarez, 2008; Súarez \& Lima-Júnior, 2009). In the Distrito Federal should be emphasized the studies of Viana (1989), Ribeiro (1994), and Aquino et al. (2009). The high endemism and, in consequence of the absence of studies, the high number of undescribed species are constantly cited in researches conducted in the region. This fact, coupled with several environmental problems resulting from uncontrolled human occupation and mismanagement of water resources, make these studies become ever more urgent.

Due to the need of information about fish assemblages in Central Brazil, extremely important data for watercourses management and conservation, this study aimed to evaluate the integrity of streams and characterize the spatial and seasonal distribution of the fish assemblage inside and outside integral protection conservation units of a sustainable use area in Distrito Federal, upper Paraná Basin, Cerrado biome.

\section{Material and Methods}

The study was conducted in a sustainable use area, the APA (in English Environmental Protection Area) Gama and Cabeça de Veado, which includes the Gama sub-basin and Cabeça de Veado stream (Fig. 1). Inside the APA, there are three integral protection conservation units: Estação Ecológica da Universidade de Brasília (EE UnB), Estação Ecológica do Jardim Botânico de Brasília (EE JBB), and Reserva Ecológica do IBGE (RE IBGE) (Fig. 1). The APA was created in 1986(Decree $9,417 / 86)$ in order to protect watercourses and Cerrado biodiversity, and to promote scientific researches (Felfili \& Santos, 2002). The climate is classified as tropical wet-dry (Köppen, 1948), characterized by a severe dry season (April to September) and a wet season (October to March). Even the APA is considered a conservation unity of sustainable use, the area suffers some environmental impacts, mainly by the occupation of Permanent Preservation Areas (APPs), especially around wetlands and water courses, trash dumping, deforestation, forest fires and unrestricted use of pesticides.

Nine stretches were sampled from Gama sub-basin and three stretches from Cabeça de Veado stream (Table 1 and Fig. 1). To standardize the sampling, during the daytime, $30 \mathrm{~m}$ stretches were sampled in the dry season, between August 13 and September 19, 2008, and the wet season, March 23 to April 10, 2009. For fish samples, because of some restrictions on the efficiency of some fishing techniques, a combination of sieves $(30 \mathrm{~cm}$ radius and $2 \mathrm{~mm}$ mesh $)$ and seines nets $(3 \times 1 \mathrm{~m}$ and $2 \mathrm{~mm}$ mesh) was used according to stretches characteristics, aiming to capture all individuals in each sample units. For deeper stretches (stretch 1), gill nets were placed for $24 \mathrm{~h}$ just to species inventory, but there was no captures with this method. Captured fishes were anaesthetized in a solution $4.5 \mathrm{mg} / \mathrm{mL}$ of lidocaine hydrochloride and then kept in a cooler with ice. This method of euthanasia is acceptable for fish according to the American Veterinary Medical Association (AVMA, 2007). Thereafter, fish were fixed in formalin solution $10 \%$ and after $48 \mathrm{~h}$, transferred to ethanol 70\% solution (Vanzolini \& Papavero, 1967; Uieda \& Castro, 1999). Voucher specimens are listed in Appendix 1. In laboratory, the weight and standard length (SL) were measured 

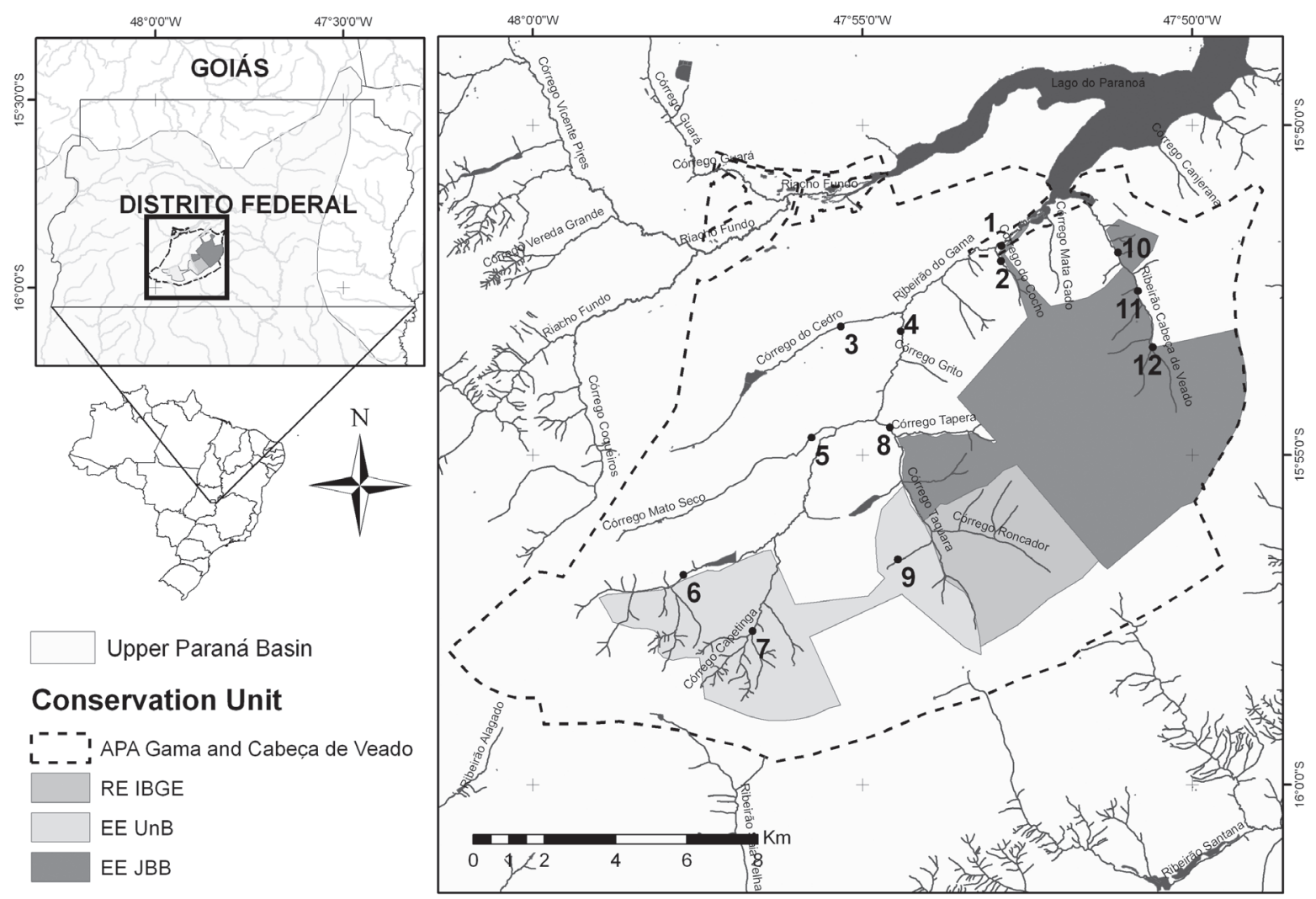

Fig. 1. Location of sampled stretches in the Gama sub-basin (1 to 9) and Ribeirão Cabeça de Veado (10 to 12). Represented in gray scales are the main integral protection conservation units (RE IBGE - Reserva Ecológica do IBGE, EE UnB - Estação Ecológica da UnB, EE JBB - Estação Ecológica do Jardim Botânico de Brasília) of APA Gama and Cabeça de Veado.

at least for 50 individuals of each species per sample unit. For Gymnotus carapo by the absence of caudal fin, was adopted the total length. Furthermore, the total mass per species in each sample unit was measured with a precise balance Marte ${ }^{\circledR}$ A200, except for individuals with more than $100 \mathrm{~g}$, that were measured with the balance Urano ${ }^{\circledR}$ UD $6000 / 1 \mathrm{~L}$.

For each $30 \mathrm{~m}$ stretch mean depth, width, water velocity (time traveled by a float at $3 \mathrm{~m}$ with three repetitions), and vegetation cover (spherical forest density measurer) were determined in three sections (downstream, $0 \mathrm{~m}$; middle, $15 \mathrm{~m}$; upstream, $30 \mathrm{~m}$ ). Water temperature, air temperature, dissolved oxygen (Winkler modified by Pomeroy \& Kirschman, 1945), pH (Schott ${ }^{\mathbb{R}}$ Handlab1), turbidity (Quimis ${ }^{\circledR}$ ) and water conductivity (Analion ${ }^{\circledR}$ C-702) were measured downstream of the stretches. The mesohabitats types were visually classified according to Rincón (1999) and the presence of substrate types (sand, silt, gravel, pebble, and litter) were described for each sample unit. The environment physical integrity was also determined visually, according to the Physical Habitat Index (PHI) proposed by Casatti et al. (2006a, 2006b). In this index, nine items that describe the riparian conditions, stream characteristics (e.g., combinations of substrate types, micro and mesohabitats) and margins stability (e.g., erosion and siltation presence) are visually evaluated. The habitat can be classified as good (PHI higher than 75\%), regular (75-50\%), poor $(50-25 \%)$ or very poor (under $25 \%$ ).
The occurrence constancy was determined by the Dajoz (1978) formula $(\mathrm{C}=\mathrm{p} / \mathrm{P} \times 100$, which $\mathrm{C}$ is the species constancy, $\mathrm{p}$ is the number of stretches with the species presence and $\mathrm{P}$ is the total number of stretches sampled). A species was considered constant when $\mathrm{C}>50 \%$. If $50 \% \geq \mathrm{C} \geq 25 \%$, it was considered accessory and accidental when $\mathrm{C}<25 \%$. The fish fauna diversity of each stretch and season was calculated by the Shannon Diversity Index (Magurran, 2004).

A species accumulation curve, expressed by the number of individuals sampled, was generated to assess the efficiency of fish sampling methodology (Gotelli \& Colwell, 2001). The curve was generated with 1,000 random permutations without replacement. To assess the inventory efficiency, the richness extrapolation estimators Chao 1 (Chao, 1987) and ACE (Abundance-based Coverage Estimator, Lee \& Chao, 1994) estimators were used. A cluster analysis was performed to observe stretches similarity according to species occurrence (Jaccard coefficient) and UPGMA linkage method (Van Tongeren, 1995). The cophenetic coefficient was generated to verify the correlation between the similarity matrix and dendrogram. To compare the stretches richness, abundance, mass, and diversity seasonality, Wilcoxon paired test (Quinn $\&$ Keough, 2002) was used. To check the influence of the distance between the stretches sampled on the fish species composition a Mantel test (999 random permutations) (Legendre \& Legendre, 1998) was carried out. A Canonical 
Table 1. Sample units located in the APA Gama and Cabeça de Veado with their respective watercourses names, coordinates, altitude (Alt), integral protection conservation units (Cons*), Physical Habitat Index (PHI), and classification (Class), exotic plant species that compose the riparian vegetation, types of mesohabitats (Meso**), and main substrate types (Sub***). ${ }^{*}$ EE JBB (Estação Ecológica do Jardim Botânico de Brasília), EE UnB (Estação Ecológica da UnB); **run (Ru), riffle (Ri), pool $(\mathrm{P}) ; * * *$ sand $(\mathrm{Sd})$, silt $(\mathrm{Si})$, gravel $(\mathrm{G})$, pebble $(\mathrm{Pe})$, and litter $(\mathrm{Li})$.

\begin{tabular}{|c|c|c|c|c|c|c|c|c|c|c|}
\hline Stretch & Watercourses & Latitude $(\mathrm{S})$ & Longitude (W) & Alt (m) & Cons* & PHI (\%) & Class & Exotic plants & Meso** & $\mathrm{Sub}^{* * *}$ \\
\hline \multicolumn{11}{|c|}{ Gama sub-basin: } \\
\hline 1 & Rib. do Gama & $15^{\circ} 51^{\prime} 49.62^{\prime \prime}$ & $47^{\circ} 52^{\prime} 53.68^{\prime \prime}$ & 1007 & EE JBB & $77.5 \pm 1.2$ & Good & - & $\mathrm{Ru}$ & $\mathrm{Sd}$ \\
\hline 2 & Córr. do Cocho & $15^{\circ} 52^{\prime} 03.43^{\prime \prime}$ & $47^{\circ} 52^{\prime} 54.08^{\prime \prime}$ & 1014 & EE JBB & $76.4 \pm 2.7$ & Good & M. indica & $\mathrm{Ru}, \mathrm{P}$ & $\mathrm{Si}$ \\
\hline 3 & Córr. do Cedro & $15^{\circ} 53^{\prime} 03.07^{\prime \prime}$ & $47^{\circ} 55^{\prime} 19.74^{\prime \prime}$ & 1020 & - & $75.0 \pm 6.3$ & Good & P. aquilinum & $\mathrm{Ru}$ & $\mathrm{Si}$ \\
\hline 4 & Rib. do Gama & $15^{\circ} 53^{\prime} 07.61^{\prime \prime}$ & $47^{\circ} 54^{\prime} 25.15^{\prime \prime}$ & 1023 & - & $77.5 \pm 0.4$ & Good & P. aquilinum, pasture & $\mathrm{Ri}, \mathrm{Ru}, \mathrm{P}$ & $\mathrm{Sd}, \mathrm{G}$ \\
\hline 5 & Córr. do Mato Seco & $15^{\circ} 54^{\prime} 44.46^{\prime \prime}$ & $47^{\circ} 55^{\prime} 46.37^{\prime \prime}$ & 1041 & - & $70.6 \pm 3.9$ & Regular & Pasture & $\mathrm{Ru}$ & $\mathrm{Sd}, \mathrm{Si}, \mathrm{G}$ \\
\hline 6 & Rib. do Gama & $15^{\circ} 56^{\prime} 49.00^{\prime \prime}$ & $47^{\circ} 57^{\prime} 43.00^{\prime \prime}$ & 1090 & EE UnB & $88.9 \pm 4.7$ & Good & - & Ri, P & $\mathrm{Sd}, \mathrm{G}$ \\
\hline 7 & Córr. Capetinga & $15^{\circ} 57^{\prime} 40.00^{\prime \prime}$ & $47^{\circ} 56^{\prime} 40.00^{\prime \prime}$ & 1097 & EE UnB & $87.5 \pm 2.0$ & Good & - & Ri, P & $\mathrm{G}, \mathrm{Pe}$ \\
\hline 8 & Córr. Taquara & $15^{\circ} 54^{\prime} 35.00^{\prime \prime}$ & $47^{\circ} 54^{\prime} 35.00^{\prime \prime}$ & 1076 & - & $85.6 \pm 0.8$ & Good & P. aquilinum, $M$. minutiflora & $\mathrm{Ri}, \mathrm{Ru}, \mathrm{P}$ & $\mathrm{Sd}, \mathrm{G}, \mathrm{Pe}$ \\
\hline 9 & Córr. da Onça & $15^{\circ} 56^{\prime} 35.00^{\prime \prime}$ & $47^{\circ} 54^{\prime} 28.00^{\prime \prime}$ & 1063 & EE UnB & $84.7 \pm 2.7$ & Good & - & $\mathrm{Ru}, \mathrm{P}$ & $\mathrm{Si}, \mathrm{Li}$ \\
\hline \multicolumn{11}{|c|}{ Cabeça de Veado stream: } \\
\hline 10 & Rib. Cab. de Veado & $15^{\circ} 51^{\prime} 55.91^{\prime \prime}$ & $47^{\circ} 51^{\prime} 07.42^{\prime \prime}$ & 1025 & EE JBB & $89.4 \pm 1.6$ & Good & - & $\mathrm{Ri}, \mathrm{Ru}, \mathrm{P}$ & $\mathrm{Sd}, \mathrm{G}, \mathrm{Pe}$ \\
\hline 11 & Rib. Cab. de Veado & $15^{\circ} 52^{\prime} 31.06^{\prime \prime}$ & $47^{\circ} 50^{\prime} 49.51^{\prime \prime}$ & 1051 & EE JBB & $86.9 \pm 2.0$ & Good & - & $\mathrm{Ru}$ & $\mathrm{Sd}, \mathrm{Pe}$ \\
\hline 12 & Rib. Cab. de Veado & $15^{\circ} 53 ’ 22.02 ”$ & $47^{\circ} 50^{\prime} 35.78^{\prime \prime}$ & 1078 & EE JBB & $95.0 \pm 1.6$ & Good & - & $\mathrm{Ri}, \mathrm{Ru}$ & $\mathrm{G}, \mathrm{Pe}, \mathrm{Li}$ \\
\hline
\end{tabular}

Correspondence Analysis (CCA, Ter Braak, 1986) was used to detect variation patterns in the fish composition assemblage along environmental gradients. The abundances of species that occurred in more than two samples were used as dependent variables. These abundances were square root transformed to reduce the effect of the most representative species, and environmental variables were logarithm transformed to reduce the effects of different scales of the measures. The influence of each environmental variable was quantified by its maximum correlation with the occurrences of the species. All analyses were performed in the statistical program $\mathrm{R}$ ( $\mathrm{R}$ Development Core Team, 2010) with 0.05 as significance level.

\section{Results}

The mean PHI was $82.9 \pm 7.5 \%(n=24)$. Only the stretch 5 showed a mean PHI lesser than a $75 \%$, being classified as regular. The remaining stretches were classified as good (Table 1). Exotic plant species were registered composing the riparian vegetation in some stretches (Table 1). Particularly, Pteridium aquilinum (L.) Kuhn. (locally called "samambaião"), Melinis minutiflora P. Beauv. (locally called "capim-gordura"), pasture and some fruit trees such as mango (Mangifera indica L.).

The species accumulation curve for the total of sampled individuals is shown in Fig. 2. Although the curve is still growing, there is a tendency towards stabilization, demonstrating good sampling efficiency. The richness estimators Chao 1 showed $25 \pm 8$ and ACE $25 \pm 2$ fish species for the streams. A total of 2,327 individuals were sampled (1.787 $\mathrm{kg}$ ), distributed in four orders, seven families, 16 genera, and 22 species (Table 2). In the dry season were sampled 1,176 individuals $(0.775 \mathrm{~kg})$ and in the wet 1,151 (1.012 kg). Among the species sampled, $50 \%$ belong to the order Characiformes, $31.8 \%$ to the order Siluriformes, $13.6 \%$ to the order Cyprinodontiformes, and $4.5 \%$ to the order Gymnotiformes. The more specious families were Characidae (31.8\%), Loricariidae (31.8\%), and Crenuchidae (13.6\%) (Table 2).

Fish fauna was characterized by small-sized specimens.
Standard length (SL) ranged from 1.0 to $20.5 \mathrm{~cm}$ (Table 2), with a mean of $3.4 \mathrm{~cm}$. About $77 \%$ had average SL lower than $5 \mathrm{~cm}$, and only two species showed average SL higher than $15 \mathrm{~cm}(G$. carapo and Hoplias malabaricus). Among the 22 sampled species, eight are still taxonomically undefined (36.4\%) and four were recently described (see Lucinda, 2008; Silveira et al., 2008; Zawadzki et al., 2008; Calegari \& Reis, 2010). The exotic species Poecilia reticulata was sampled in the stretches 4 and 5 during the wet season, for a total of four individuals. Knodus moenkhausii was the most abundant species with 1,476 individuals ( $63.4 \%$ of the total abundance), followed by Astyanax sp. (19.4\%), Phalloceros harpagos (6.6\%), and Hasemania sp. (5.8\%) (Table 2). Constant species during the wet and dry seasons were Astyanax sp. and K. moenkhausii. Hasemania sp., Hypostomus sp.2, and P. harpagos were considered accessories. The remaining species fall into the accidental category (Table 2). For mass, K. moenkhausii had the highest participation with $755.7 \mathrm{~g}$ ( $42.3 \%$ of the total mass), followed by Astyanax sp. (35.2\%), H. malabaricus (10.5\%), and Hypostomus sp. 2 (4.9\%) were also representative (Table 2).

Between seasons (Table 3), no significant differences in species richness $(\mathrm{W}=75 ; \mathrm{p}=0.88)$, diversity $(\mathrm{W}=72 ; \mathrm{p}=0.99)$,

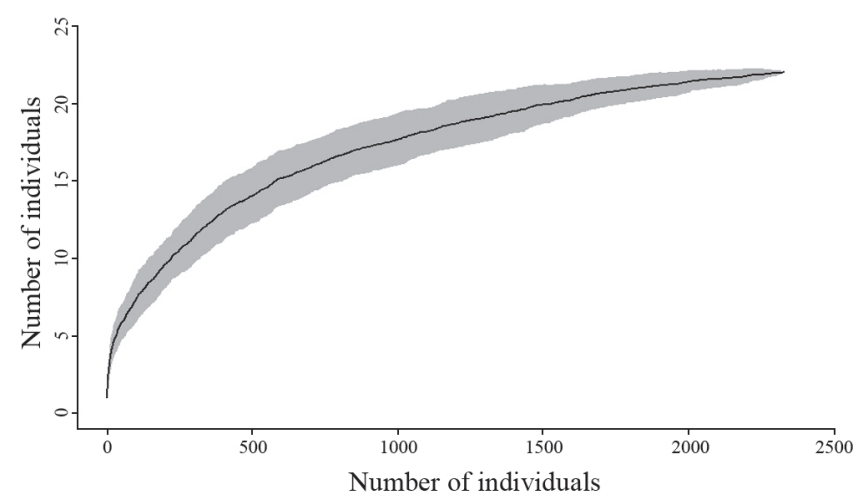

Fig. 2. Species accumulation curve and standard error (gray) generated from permutations of sampled individuals in streams of the APA Gama and Cabeça de Veado. 
Table 2. Fish species sampled in the APA Gama and Cabeça de Veado with their number of individuals (N) and mass (M) of each species in total (T), dry (D), and wet (W) seasons, occurrence constancy (C), and standard length (SL) range. *Exotic species, **total length. Family group names follow Reis et al., 2003).

\begin{tabular}{|c|c|c|c|c|c|c|c|c|}
\hline \multirow[t]{2}{*}{ Taxon } & \multicolumn{3}{|c|}{$\mathrm{N}$} & \multicolumn{3}{|c|}{$\mathrm{M}(\mathrm{g})$} & \multirow{2}{*}{$\begin{array}{l}\mathrm{C} \\
-(\%)\end{array}$} & \multirow{2}{*}{$\begin{array}{c}\mathrm{SL} \\
(\mathrm{cm})\end{array}$} \\
\hline & $\mathrm{T}$ & $\mathrm{D}$ & $\mathrm{W}$ & $\mathrm{T}$ & $\mathrm{D}$ & $\mathrm{W}$ & & \\
\hline \multicolumn{9}{|l|}{ Order Characiformes } \\
\hline \multicolumn{9}{|l|}{ Family Cren uchidae } \\
\hline Characidium sp. & 18 & 11 & 7 & 14.1 & 8.2 & 5.9 & 83 & $3.4-4.9$ \\
\hline Characidium xanthopterum Silveira, Langeani, Graça, Pavanelli \& Buckup, 2008 & 5 & 5 & - & 2.9 & 2.9 & - & 83 & $32-3.8$ \\
\hline Characidium zebra Eigenmann, 1909 & 4 & 3 & 1 & 0.9 & 0.5 & 0.4 & 83 & $19-3.0$ \\
\hline \multicolumn{9}{|l|}{ Family Characidae } \\
\hline \multicolumn{9}{|l|}{ Subfamily Glandulocaudinae } \\
\hline Planaltina myersi Böhlke, 1954 & 5 & 2 & 3 & 2.8 & 1.3 & 1.5 & 16.7 & $3.4-4.1$ \\
\hline \multicolumn{9}{|l|}{ Genera incertae sedis } \\
\hline As tyanax $\mathrm{sp}$. & 451 & 174 & 277 & 629.9 & 293.8 & 336.2 & 79.2 & $1.0-8.3$ \\
\hline Bryconamericus stramineus Eigenmann, 1908 & 3 & - & 3 & 4.0 & - & 4.0 & 42 & $4.5-5.2$ \\
\hline Hasemania sp. & 136 & 56 & 80 & 23.4 & 5.8 & 17.6 & 29.2 & $1.1-3.1$ \\
\hline Knodus moenkhausii (Eigenmann \& Kennedy, 1903) & 1,476 & 786 & 690 & 755.7 & 349.3 & 406.4 & 50.0 & 1.14 .8 \\
\hline Moenkhausia sp. & 7 & 4 & 3 & 5.3 & 1.9 & 3.5 & 12.5 & 2.14 .2 \\
\hline Piabina argentea Reinhard t, 1867 & 14 & 14 & - & 19.1 & 19.1 & - & 83 & $4.0-4.7$ \\
\hline \multicolumn{9}{|l|}{ Family Erythrinidae } \\
\hline Hoplias malabaricus (Bloch, 1794) & 1 & - & 1 & 187.0 & - & 187.0 & 42 & 20.5 \\
\hline \multicolumn{9}{|l|}{ Order Siluriformes } \\
\hline \multirow{2}{*}{\multicolumn{9}{|c|}{$\begin{array}{l}\text { Family Lori cariidae } \\
\text { Subfamily Hyp op topomat inae }\end{array}$}} \\
\hline & & & & & & & & \\
\hline Microlepidogaster longicolla Calegari \& Reis, 2010 & 4 & 4 & - & 1.9 & 1.9 & - & 42 & $2.4-3.7$ \\
\hline \multicolumn{9}{|l|}{ Subfamily Hypos tominae } \\
\hline Hypostomus ancistroides (Ihering, 1911) & 3 & 3 & - & 0.9 & 0.9 & - & 42 & $2.3-2.8$ \\
\hline Hypostomus sp. 1 & 1 & 1 & - & 6.3 & 6.3 & - & 42 & 6.5 \\
\hline Hypostomus sp. 2 & 34 & 29 & 5 & 87.7 & 63.4 & 24.3 & 25.0 & $1.6-7.4$ \\
\hline Hypostomus sp. 3 & 1 & 1 & - & 1.7 & 1.7 & - & 42 & 4.3 \\
\hline Hypostomus sp.4 & 1 & - & 1 & 9.6 & - & 9.6 & 42 & 7.3 \\
\hline \multicolumn{9}{|l|}{ Subfamily Neoplecostominae } \\
\hline Neoplecostomus corumba Zawadzki, Pavanelli \& Langeani, 2008 & 2 & - & 2 & 5.8 & - & 5.8 & 42 & $4.8-6.8$ \\
\hline \multicolumn{9}{|l|}{ Order Gymnotiformes } \\
\hline \multicolumn{9}{|l|}{ Family Gymnotidae } \\
\hline Gymnotus carapo Linnaeus, 1758 & 1 & 1 & - & 7.5 & 7.5 & - & 42 & $15.9^{* *}$ \\
\hline \multicolumn{9}{|l|}{ Order Cyprinodontiformes } \\
\hline \multicolumn{9}{|l|}{ Family Rivulidae } \\
\hline Ri vulus pictus Costa, 1989 & 2 & 1 & 1 & 1.5 & 0.6 & 0.9 & 83 & $3.4-3.4$ \\
\hline \multicolumn{9}{|l|}{ Family Poecilii dae } \\
\hline Phalloceros harpagos Lucinda, 2008 & 154 & 81 & 73 & 19.1 & 10.1 & 9.0 & 25.0 & $12-2.9$ \\
\hline Poecilia reticulata Peters, $1859^{*}$ & 4 & - & 4 & 0.4 & - & 0.4 & 8.3 & $15-2.0$ \\
\hline
\end{tabular}

abundance $(\mathrm{W}=72.5 ; \mathrm{p}=0.99)$, and mass $(\mathrm{W}=74 ; \mathrm{p}=0.93)$ were recorded. No influence in the distances between the sampled stretches on the fish species composition (Mantel test; $\mathrm{r}=0.09 ; \mathrm{p}=0.06$ ) was observed.

The cluster analysis showed a more marked spatial differences in species composition than seasonal differences, with groups representing stretches located farther (A) and closer (B) of headwaters (Fig. 3). Abundant and frequent species as K. moenkhausii and Hasemania sp. were absent in B stretches (i.e., absent in headwaters). In contrast, Astyanax sp. was present in all B stretches, but absent or rare in A group. Similar pattern was observed in Ribeirão Cabeça de Veado, where more upstream stretches (i.e., 11 and 12) showed higher similarity with Gama sub-basin headwaters than with its own downstream stretch (i.e., with stretch 10). Between seasons only sites 2 and 12 demonstrated little variation.

The Canonical Correspondence Analysis (CCA) showed that the environmental variables (Table 4 ) explained $64 \%$ of the variation in the fish species abundance $(25 \%$ in the first and $16 \%$ in the second canonical axis). The most important variables in fish assemblage were altitude, water velocity, PHI, pebble, sand, width, riffle, and silt (Table 5). The species Planaltina myersi, Bryconamericus stramineus, Moenkhausia sp., Hasemania sp., G. carapo, Hypostomus sp.3, P. reticulata, K. moenkhausii, H. malabaricus, Hypostomus sp.4, and Hypostomus ancistroides were present, especially, in low altitude and deeper stretches (Fig. 4). Despite having a wide distribution in APA, Astyanax sp. and Rivulus pictus demonstrated preferences for shallower stretches (Fig. 4). Neoplecostomus corumba, Characidium sp., Hypostomus sp.1, Microlepidogaster longicolla, Piabina argentea, Hypostomus sp. 2, and Characidium xanthopterum occurred primarily in stretches with higher water velocity and altitude. Phalloceros harpagos occurred in narrow stretches with lower water velocity and presence of silt. Characidium zebra was correlated with wide stretches with higher water velocity and presence of sand (Fig. 4). Characidium xanthopterum was strongly correlated to PHI, in contrast to P. myersi, B. stramineus, Moenkhausia sp., Hasemania sp., G. carapo, Hypostomus sp.3, P. reticulata, K. moenkhausii, $H$. malabaricus, Hypostomus sp.4, and H. ancistroides, which were negatively correlated with that variable (Fig. 4). 
Table 3. Species richness, Shannon diversity (H'), abundance and mass of fish sampled in dry (D) and wet (W) seasons in stream stretches of the APA Gama and Cabeça de Veado.

\begin{tabular}{ccccccccc}
\hline \multirow{2}{*}{ Stretch } & \multicolumn{2}{c}{ Richness } & \multicolumn{2}{c}{ H'$^{\prime}$} & \multicolumn{2}{c}{ Abundance } & \multicolumn{2}{c}{ Mass (g) } \\
\cline { 2 - 9 } & $\mathrm{D}$ & $\mathrm{W}$ & $\mathrm{D}$ & $\mathrm{W}$ & $\mathrm{D}$ & $\mathrm{W}$ & $\mathrm{D}$ & $\mathrm{W}$ \\
\hline 1 & 4 & 4 & 0.40 & 0.14 & 295 & 248 & 85.7 & 91.7 \\
2 & 2 & 2 & 0.69 & 0.65 & 138 & 108 & 118.3 & 71.4 \\
3 & 4 & 3 & 0.41 & 0.28 & 69 & 74 & 44.8 & 55.4 \\
4 & 6 & 8 & 0.65 & 0.83 & 300 & 265 & 116.1 & 333.1 \\
5 & 5 & 7 & 0.19 & 0.59 & 122 & 80 & 66.0 & 51.7 \\
6 & 2 & 1 & 0.13 & 0.00 & 34 & 12 & 75.7 & 8.5 \\
7 & 1 & 1 & 0.00 & 0.00 & 6 & 168 & 7.0 & 164.0 \\
8 & 8 & 6 & 1.85 & 1.02 & 74 & 62 & 101.3 & 64.0 \\
9 & 2 & 2 & 0.33 & 0.69 & 10 & 2 & 17.2 & 0.9 \\
10 & 2 & 2 & 0.27 & 0.39 & 78 & 99 & 59.9 & 93.2 \\
11 & 1 & 1 & 0.00 & 0.00 & 19 & 7 & 13.9 & 11.8 \\
12 & 2 & 2 & 0.38 & 0.16 & 31 & 26 & 69.1 & 66.8 \\
\hline Total & 17 & 15 & - & - & 1,176 & 1,151 & 775 & 1,012 \\
\hline
\end{tabular}

\section{Discussion}

The orders Characiformes and Siluriformes totalized $81.8 \%$ of APAs fish species. This fact is also widely observed in streams of the upper rio Paraná system (Castro et al., 2003; Langeani et al., 2007), which reflects the patterns of Brazil and the Neotropics (Lowe-McConnell, 1987; Castro, 1999; Reis et al., 2003; Buckup et al., 2007). As the pattern also found in the APA, the small size is a general characteristic of headwaters stream fishes of South America (Castro, 1999). This fact allows these species to colonize environments with specific microhabitats and reduced physical dimensions, spending all their life cycle in a geographically restricted area. One consequence of this process would be the high rate of allopatric speciation (Castro, 1999). This idea is supported by the high number of undescribed species or in undefined taxonomic situation (Castro et al., 2003; Buckup et al., 2007; Langeani et al., 2007; Valério et al., 2007; Aquino et al., 2009).

As well as in other studies in upper rio Paraná system, including Distrito Federal (Aquino et al., 2009) and São Paulo State (Casatti et al., 2006b; Ceneviva-Bastos \& Casatti, 2007), $K$. moenkhausii was registered as the most abundant species. According to Langeani et al. (2007), this species is not originally from the upper Paraná drainage, and its introduction may be related to Itaipu dam construction, finished in 1982 (Agostinho et al., 2007). The dominance of the species $K$. moenkhausii, adapted to tolerate sites where the riparian vegetation is not preserved, primarily without feeding preferences between allochthonous and autochthonous items, can be explained by its large feeding plasticity (CenevivaBastos \& Casatti, 2007). The second representative species in terms of abundance was Astyanax sp., similarly to that observed by Ribeiro (1994) and Aquino et al. (2009). This species has a great colonization capacity, and in some headwater stretches was the unique species sampled. Although more frequent in headwaters, it was also present, even unrepresentative, in larger water volume stretches. Moreover, Astyanax sp., classified as omnivorous with herbivory tendency, has great feeding plasticity, consuming materials from animal origin and mainly superior plants parts with allochthonous origin (Schneider, 2008).

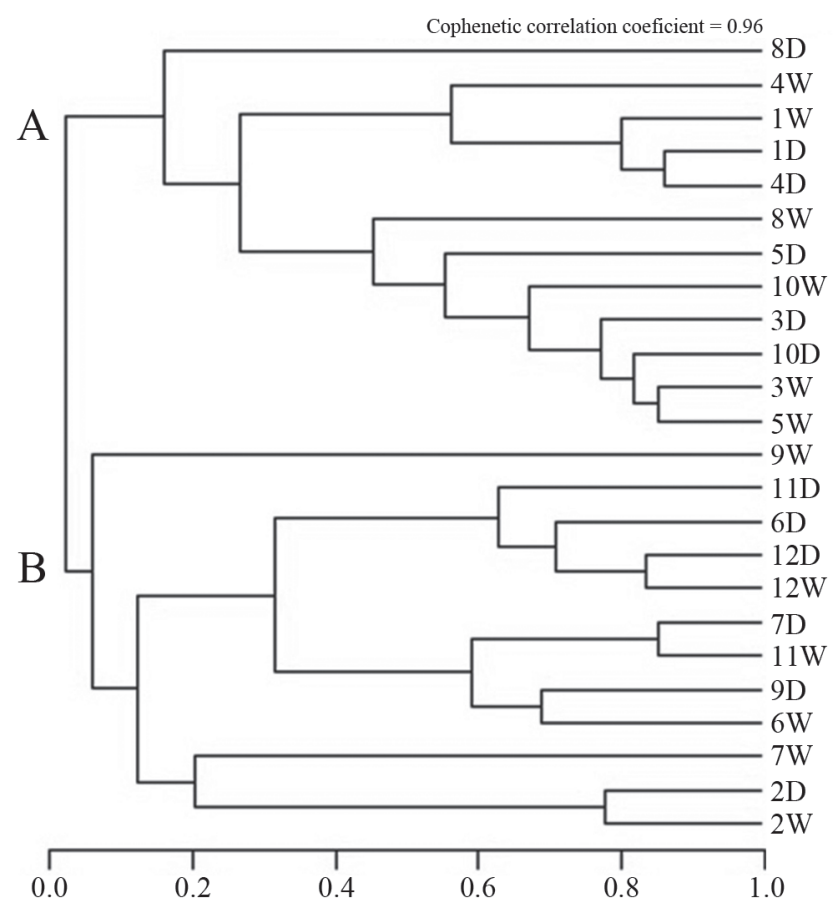

Fig. 3. Similarity dendrogram of stretches based on fish species occurrence from dry (D) and wet (W) seasons in streams of the APA Gama and Cabeça de Veado. Note the two groups that represent farther $(\mathbf{A})$ and closer $(\mathbf{B})$ of headwaters.

Despite the rainfall influence on the migratory cycles targeted to feeding sites, and specially to reproductive activities in fish assemblages (Agostinho, 2004), the low seasonal influence on headwater streams ichthyofauna has been observed in upper Paraná basin studies, where spatial variation are more relevant to species distribution than seasonal variations, at least for most species (Langeani et al., 2005; Valério et al., 2007; Aquino, 2008; Súarez, 2008; Súarez \& LimaJúnior, 2009). The low seasonal variation in fish assemblages of headwaters can be related to the higher stability (i.e., tendency to reduce fluctuations in the energy flow) in these systems when compared to high order streams. Systems physically more stable, as headwaters (e.g., low radiation incidence, clear and cold waters, and allochthonous organic matter input relatively constant during all the year), tend to have a minor contribution of the biota on ecosystem stability, maintaining favorable conditions for few species in both seasons (Vannote et al., 1980).This fact may be related to the perennial riparian vegetation dynamics, which hold stream characteristics with low seasonal influence (Ribeiro \& Walter, 1998).

According to Poff (1997), hydrological variables act as filters in lotic environments for species able to colonization, unlike biotic relationships that, generally, do not exert much influence on the composition of ichthyofauna in headwaters when compared to habitat specializations and colonization-extinction dynamics (Peres-Neto, 2004). For some species of the APA, as $K$. moenkhausii and Hasemania sp., it is evident that those filters were directly related to water volume and habitat complexity, however, for Astyanax sp., they were inversely related. 
Table 4. Environmental variables sampled in the streams of the APA Gama and Cabeça de Veado during dry (D) and wet (W) seasons. Width, depth, vegetation cover $(\mathrm{VC})$, water velocity (Vel), air temperature (Ta), water temperature (Tw), $\mathrm{pH}$, water conductivity (Cond), dissolved oxygen (DO), and turbidity (Turb).

\begin{tabular}{|c|c|c|c|c|c|c|c|c|c|c|c|c|c|c|c|c|c|c|c|c|}
\hline \multirow[t]{2}{*}{ Stretch } & \multicolumn{2}{|c|}{ Width $(\mathrm{cm})$} & \multicolumn{2}{|c|}{ Depth $(\mathrm{cm})$} & \multicolumn{2}{|c|}{ VC (\%) } & \multicolumn{2}{|c|}{$\operatorname{Vel}(\mathrm{m} / \mathrm{s})$} & \multicolumn{2}{|c|}{$\mathrm{Ta}\left({ }^{\circ} \mathrm{C}\right)$} & \multicolumn{2}{|c|}{$\mathrm{Tw}\left({ }^{\circ} \mathrm{C}\right)$} & \multicolumn{2}{|c|}{$\mathrm{pH}$} & \multicolumn{2}{|c|}{ Cond $\left(\mu \mathrm{S} / \mathrm{cm}^{2}\right)$} & \multicolumn{2}{|c|}{ DO $(\mathrm{mg} / \mathrm{L})$} & \multicolumn{2}{|c|}{ Turb (NTU) } \\
\hline & $\mathrm{D}$ & $\mathrm{W}$ & $\mathrm{D}$ & $\mathrm{W}$ & $\mathrm{D}$ & W & $\mathrm{D}$ & $\mathrm{W}$ & $\mathrm{D}$ & $\mathrm{W}$ & $\mathrm{D}$ & $\mathrm{W}$ & $\mathrm{D}$ & $\mathrm{W}$ & $\mathrm{D}$ & $\mathrm{W}$ & $\mathrm{D}$ & W & $\mathrm{D}$ & $\mathrm{W}$ \\
\hline 1 & 686 & 702 & $\overline{92}$ & 129 & 63.9 & 72.2 & 0.2 & 0.4 & 19.5 & 23.0 & 16.0 & 22.0 & 7.4 & 5.0 & 20.2 & 12.1 & 7.4 & 7.9 & 7.4 & 33.0 \\
\hline 2 & 91 & 137 & 45 & 71 & 80.6 & 60.4 & 0.1 & 0.0 & 23.0 & 26.0 & 17.0 & 23.0 & 5.5 & 4.8 & 5.5 & 6.3 & 7.4 & 7.8 & 9.0 & 4.0 \\
\hline 3 & 108 & 173 & 49 & 44 & 87.5 & 88.9 & 0.4 & 0.4 & 23.0 & 25.0 & 19.0 & 23.0 & 5.7 & 5.3 & 15.0 & 17.8 & 6.8 & 7.9 & 9.8 & 4.1 \\
\hline 4 & 689 & 741 & 80 & 117 & 45.8 & 53.5 & 0.5 & 0.6 & 23.0 & 25.0 & 17.0 & 22.0 & 5.8 & 5.0 & 19.1 & 14.5 & 7.5 & 5.7 & 5.9 & 8.5 \\
\hline 5 & 139 & 183 & 49 & 73 & 76.4 & 86.1 & 0.2 & 0.5 & 25.0 & 26.0 & 21.0 & 23.0 & 6.5 & 5.2 & 80.8 & 36.5 & 5.4 & 6.7 & 7.9 & 5.2 \\
\hline 6 & 278 & 435 & 37 & 36 & 80.6 & 71.5 & 0.4 & 0.7 & 22.0 & 22.0 & 19.0 & 21.0 & 5.3 & 6.1 & 4.5 & 8.7 & 5.6 & 6.7 & 7.7 & 5.2 \\
\hline 7 & 215 & 404 & 23 & 26 & 63.9 & 73.6 & 0.3 & 0.4 & 21.0 & 24.5 & 19.0 & 22.0 & 5.3 & 6.2 & 3.7 & 2.7 & 5.5 & 8.4 & 3.9 & 6.0 \\
\hline 8 & 397 & 422 & 47 & 56 & 48.6 & 69.4 & 0.7 & 0.9 & 29.0 & 23.0 & 20.0 & 21.5 & 5.6 & 6.6 & 3.1 & 3.3 & 6.9 & 7.1 & 6.1 & 4.0 \\
\hline 9 & 202 & 198 & 47 & 52 & 93.1 & 91.7 & 0.4 & 0.4 & 23.0 & 22.0 & 20.0 & 22.0 & 5.3 & 6.3 & 2.3 & 2.7 & 6.3 & 6.0 & 2.5 & 2.5 \\
\hline 10 & 341 & 363 & 61 & 63 & 90.3 & 90.3 & 0.2 & 0.2 & 24.0 & 23.5 & 16.0 & 21.0 & 6.3 & 4.9 & 9.3 & 5.8 & 7.3 & 8.1 & 4.3 & 7.9 \\
\hline 11 & 235 & 253 & 83 & 90 & 87.5 & 72.9 & 0.1 & 0.1 & 18.0 & 20.4 & 16.5 & 22.0 & 6.6 & 4.9 & 10.8 & 5.6 & 7.8 & 8.3 & 6.5 & 1.6 \\
\hline 12 & 271 & 274 & 25 & 21 & 93.1 & 93.1 & 0.4 & 0.5 & 21.0 & 22.0 & 18.0 & 21.0 & 5.5 & 4.9 & 4.3 & 3.2 & 6.9 & 7.9 & 3.4 & 2.2 \\
\hline
\end{tabular}

Apparently, natural seasonal changes in APA do not exert major alterations in these filters. However, little seasonal influence may be scale dependent (see Fig. 3), in which fluctuations in similarity between stretches within each subdivision $\mathrm{A}$ and $\mathrm{B}$ could be observed. As a consequence of small scale alterations of mesohabitats, mainly by natural hydrological changes related to seasons or not, short movements of fishes due habitat preference can be stimulated. Small changes in depth, water flow and substrates (i.e., riparian roots, macrophytes, litter) to feed, shelter, and reproduce can stimulate these short movements for sites that remain more favorable characteristics.

In natural lotic environments, along its longitudinal gradient (i.e., for downstream), there is an increase in water volume and, consequently, in habitat complexity and food availability, that support more species (Vannote et al., 1980). Therefore, we expect lower richness and higher dependence of allochthonous input in headwaters when compared to downstream waters (Vannote et al., 1980). In fact, more complex stretches presented higher richness in the study, which was also reported by several studies (Viana, 1989; Aquino, 2008; Hitt \& Angermeier, 2008; Ibañez et al., 2009). Through the CCA, variables that more influenced species distribution patterns in the APA were related directly or indirectly to the water volume and habitats complexity. Several studies point out the altitude and hydrological variables (i.e., depth, width, and water velocity) as the those that best describe the distribution patterns and assemblage structure of headwaters fishes of Central Brazil (Valério et al., 2007; Aquino, 2008; Súarez \& Lima-Júnior, 2009). In addition to these, riparian vegetation characteristics and the combination of types of mesohabitats and substrates should be emphasized according to their importance documented in several studies (Jones et al., 1999; Casatti et al., 2006a; Ferreira \& Casatti, 2006; Teresa \& Romero, 2010). As an example of mesohabitat influences, Langeani et al. (2005) compared the ichthyofauna between a riffle and a pool from a Tietê river tributary and concluded that the pool was the more diverse mesohabitat. The authors attributed this fact to the habitat complexity (e.g., presence of submerged vegetation and substrates combination) and the higher water volume that contribute to greater food availability and, consequently, niches to be explored.

In general, the APA streams are relatively well preserved
Table 5. Results of Canonical Correspondence Analysis (canonical coefficients [CCA1 and CCA2] and squared correlation coefficients $\left[\mathrm{r}^{2}\right]$ ), of fish assemblages and environmental variables in streams of the APA Gama and Cabeça de Veado. *Significant for $\alpha \leq 0.05, * *$ significant foror $\alpha \leq 0.01$, $* * *$ significant for or $\alpha \leq 0.001$.

\begin{tabular}{lccc}
\hline Variables & CCA1 & CCA2 & $\mathrm{r}^{2}$ \\
\hline Season & 0.681 & 0.732 & 0.005 \\
pH & 0.962 & -0.274 & 0.036 \\
Dissolved oxygen & -0.957 & 0.292 & 0.033 \\
Conductivity & 0.838 & 0.546 & 0.347 \\
Cover & -0.671 & 0.741 & 0.169 \\
Width & 0.919 & -0.393 & $0.336^{*}$ \\
Depth & 0.948 & 0.318 & $0.371^{*}$ \\
Velocity & 0.324 & -0.946 & $0.601^{* * *}$ \\
Turbidity & 0.932 & 0.362 & 0.122 \\
Water temperature & -0.268 & -0.963 & 0.014 \\
Air temperature & 0.107 & -0.994 & 0.123 \\
Physical habitat index & -0.685 & -0.728 & $0.520^{* *}$ \\
Run & 0.972 & 0.236 & 0.237 \\
Riffle & -0.075 & -0.997 & $0.415^{*}$ \\
Pool & -0.753 & -0.658 & 0.214 \\
Sand & 0.879 & -0.477 & $0.533^{* *}$ \\
Silt & -0.285 & 0.959 & $0.359^{*}$ \\
Gravel & 0.209 & -0.978 & 0.300 \\
Pebble & -0.446 & -0.895 & $0.513^{* *}$ \\
Litter & -0.926 & -0.378 & 0.164 \\
Altitude & -0.593 & -0.806 & $0.734^{* * *}$ \\
Conservation units & -0.920 & -0.392 & 0.327 \\
\hline
\end{tabular}

(mean PHI 82.9 $7.5 \%$ ), but in some stretches anthropogenic influences were registered, notably in water quality and riparian vegetation integrity and composition. According to Esteves (1998), water conductivity can detect pollution sources in aquatic ecosystems. If compared to other sub-basin stretches, outliers were recorded on Córrego Mato Seco (stretch 5) conductivity, indicating an over input of allochthonous organic matter, possibly by domestic sewage and by agricultural activities. The invasive plants Pteridium aquilinum ("samambaião") and Melinis minutiflora ("capim-gordura") compete assiduously with native species, thus reducing plant diversity (Pivello et al., 1999; Marrs $\&$ Watt, 2006). The presence of these two species composing the riparian vegetation in some stretches is probably related to forest clearing (i.e., increase of light availability), strong evidence of forest fires and other human activities (Pivello et al., 1999; Mistry \& Berardi, 2005). 


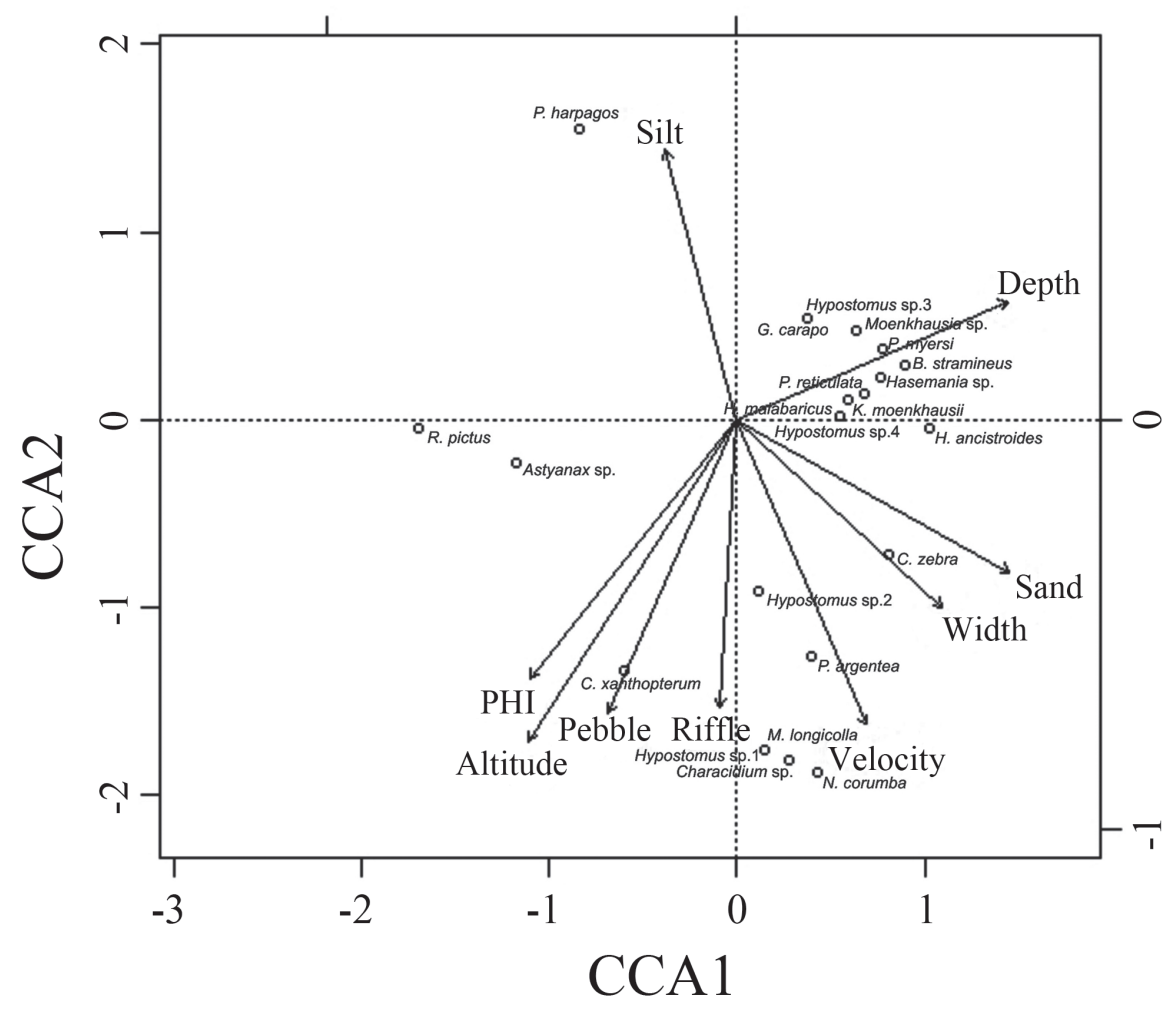

Fig. 4. Biplot of the two first axis resulting from Canonical Correspondence Analysis (CCA) showing fish species scores (open circles) and significant environmental variables (arrows) in streams of the APA Gama and Cabeça de Veado.

The misuse of land and the riparian vegetation deforestation contribute to a marked habitat quality loss in aquatic ecosystems, which leads the dominance of generalist fish species (Casatti et al., 2006a). Continuous physical and chemical alterations of natural conditions of streams caused by human activity support the establishment of exotic fish species. In minimally disturbed habitats, the most successful fish invaders tend to be omnivores/ detritivores or piscivores (Moyle \& Light, 1996). As observed in this study, Casatti et al. (2006a, 2006b) showed that the structure of fish assemblage has strong correlation with the habitat physical conditions. The presence of the exotic species $P$. reticulata, tolerant to hypoxia and detritivorous species (Casatti et al., 2009), is strongly correlated with variables of degraded habitats, primarily associated with streams siltation. In extremely impacted stretches, this species is able to hold more than $50 \%$ of fish fauna abundance (Casatti et al., 2006a, 2006b; Cunico et al., 2006; Casatti et al., 2009). Fitzgerald et al. (1998), studying Canadian impacted streams, suggests that changes in structure of fish assemblage and replacement of species do not happen immediately and may take many years. The four $P$. reticulata individuals sampled only during the wet season in sample units 4 (middle Ribeirão do Gama) and 5 (Córrego Mato Seco), showed that the species is not well established in the area yet, but it's starting to colonize some stretches, especially those with low habitat quality. Other species, such as G. carapo and $H$. ancistroides, sampled in stretches 4 and 5, are also reported as common in degraded habitats, especially due to their tolerance to hypoxia (Cunico et al., 2006; Casatti et al., 2009). According to
Casatti et al. (2006b), K. moenkhausii can also be benefited by siltation, mainly by its preference for habitats with particulate substrate (i.e., silt and sand) due to its generalist feeding habit. Ribeiro (1994) compared the biotic integrity of fish fauna in Gama sub-basin between the years 1986 and 1991, and concluded that there was a generalized depletion of the fish fauna throughout the sub-basin. Like the present study, he emphasized the Ribeirão do Gama and Córrego Mato Seco as the watercourses most affected by human activities. Based on data from the present study, C. xanthopterum can be considered as indicator of physically preserved habitats.

The APA Gama and Cabeça de Veado streams are relatively well preserved, despite some human activities, mainly outside the integral protected areas. Among these activities, clearing of riparian vegetation deserves attention, since its integrity is a remarkable component for the maintenance of the ichthyofauna structure. The high number of undescribed fish species sampled in this and other studies corroborate that more samples in Central Brazil streams are extremely necessary.

Despite the study limitations, mainly the number of samplings, it is evident that there is an enormous amount of basic information to be known which is essential for understanding, managing and for stream fishes and aquatic resources from Cerrado biome conservation. The large number of endemic species and the rapid habitat loss in this biome make necessary urgent efforts, notably long-term studies, taxonomic inventories, and species biology studies (e.g., feeding, reproduction). 


\section{Acknowledgements}

We thank for Ronan Paiva, Tiago de Melo, and Gustavo Leite by helping in the field and laboratory procedures. For Marcos de Paula, Guth Rodrigues, Bruno Santos, Lucas Cunha, and Priscila Cunha by fish collecting assistance. Mardônio Timo by helping in campaigns. June Springer de Freitas and Maria do Socorro Rodrigues by the academic support. For Leonardo Giordano to improve the English version. Maria Regina Silva and Viviane Miranda for chemical analysis assistance. Lilian Casatti and two anonymous referees for valuable suggestions. Programa de Iniciação Científica (PIC/ UnB) for scholarship to TBAC. Jardim Botânico de Brasília (JBB) and Fazenda Água Limpa (FAL) for the logistic support. License grant from IBAMA (16365/2) and CEUA(UNBDOC 41141/2008).

\section{Literature Cited}

Agostinho, A. A., L. C. Gomes \& F. M. Pelicice. 2007. Ecologia e manejo de recursos pesqueiros em reservatórios do Brasil. Maringá, Eduem, 502p.

Agostinho, A. A., L. C. Gomes, H. I. Suzuki \& H. F. Júlio Jr. 2004. Migratory fishes of the upper Paraná river basin. Pp. 19-98. In: Carolsfeld, J., B. Harvey, C. Ross \& A. Baer (Eds.). Migratory fishes of South America: biology, fisheries and conservation status. British Columbia, Canada, World Fisheries Trust, 380p.

Aquino, P. P. U. 2008. Distribuição da taxocenone íctica em córregos de cabeceira da bacia do Alto Rio Paraná, DF. Unpublished M.Sc. Dissertation, Universidade de Brasília, Brasília, 50p.

Aquino, P. P. U., M. Schneider, M. J. Martins-Silva, C. PadovesiFonseca, H. B. Arakawa \& D. R. Cavalcanti. 2009. Ictiofauna dos córregos do Parque Nacional de Brasília, bacia do Alto Rio Paraná, Distrito Federal, Brasil Central. Biota Neotropica, 9: 217-230.

Araújo, N. B. \& F. L. Tejerina-Garro. 2007. Composição e diversidade da ictiofauna em riachos do Cerrado, bacia do ribeirão Ouvidor, alto rio Paraná, Goiás, Brasil. Revista Brasileira de Zoologia, 24: 981-990.

AVMA Guidelines on Euthanasia. 2007. Formerly Report of the AVMA Panel on Euthanasia. American Journal of Veterinary Research, 68: 921-924.

Benedito-Cecilio, E., C. V. Minte-Vera, C. H. Zawadzki, C. S. Pavanelli, F. H. G. Rodrigues \& M. F. Gimenes. 2004. Ichthyofauna from the Emas National Park region: composition and structure. Brazilian Journal of Biology, 64: 371-382.

Buckup. P. A., N. A. Menezes \& M. S. Ghazzi. 2007. Catálogo das espécies de peixes de água doce do Brasil. Rio de Janeiro, Museu Nacional, 195p.

Calegari, B. B. \& R. E. Reis. 2010. A new species of Microlepidogaster (Siluriformes: Loricariidae: Hypoptopomatinae) from the upper rio Paraná basin, Brazil. Neotropical Ichthyology, 8: 625-630.

Casatti, L., C. P. Ferreira \& F. Langeani. 2009. A fish-based biotic integrity index for assessment of lowland streams in southeastern Brazil. Hydrobiologia, 623: 173-189.

Casatti, L., F. Langeani \& C. P. Ferreira. 2006a. Effects of the physical habitat degradation on the stream fish assemblage structure in a pasture region. Environmental Management, 38: 974-982.

Casatti, L., F. Langeani, A. M. Silva \& R. M. C. Castro. 2006b. Stream fish, water and habitat quality in a pasture dominated basin, southeastern Brazil. Brazilian Journal of Biology, 66: 681-696.
Castro, R. M. C. \& N. A. Menezes. 1998. Estudo diagnóstico da diversidade do Estado de São Paulo. Pp. 1-13. In: Joly, C. A. \& C. E. M. Bicudo (Orgs.). Biodiversidade do Estado de São Paulo, Brasil: síntese do conhecimento ao final do século XX. Vol. 6. São Paulo, Winner Graph, FAPESP, 71p.

Castro, R. M. C. 1999. Evolução da ictiofauna de riachos sul-americanos: padrões gerais e possíveis processos causais. Pp. 139155. In: Caramaschi, E. P., R. Mazzoni \& P. R. Peres-Neto (Eds.). Ecologia de peixes de riachos. Série Oecologica Brasilensis, vol. VI. Rio de Janeiro, Brasil, PPGE-UFRJ, 260p.

Castro, R. M. C., L. Casatti, H. F. Santos, K. M. Ferreira, A. C. Ribeiro, R. C. Benine, G. Z. P. Dardis, A. L. A. Melo, R. Stopliglia, T. X. Abreu, F. A. Bockmann, M. Carvalho, F. Z. Gibran \& F. C. T. Lima. 2003. Estrutura e composição da ictiofauna de riachos do Rio Paranapanema, Sudeste e Sul do Brasil. Biota Neotropica, 3: 1-31.

Ceneviva-Bastos, M. \& L. Casatti. 2007. Oportunismo alimentar de Knodus moenkhausii (Teleostei: Characidae): uma espécie abundante em riachos do noroeste do Estado de São Paulo, Brasil. Iheringia. Série Zoologia, 97: 7-15.

Chao, A. 1987. Estimating the population size for capture-recapture data with unequal catchability. Biometrics, 43: 783-791.

Cunico, A. M., A. A. Agostinho \& J. D. Latini. 2006. Influência da urbanização sobre as assembléias de peixes em três córregos de Maringá, Paraná. Revista Brasileira de Zoologia, 23: 1101-1110.

Dajoz, R. 1978. Ecologia Geral. Editora Vozes, Rio de Janeiro, 472p.

Esteves, F. A. 1998. Fundamentos de limnologia. Interciência, Rio de Janeiro, 602p.

Felfili, J. M. \& A. A. B. Santos. 2002. Legislação Ambiental: APA Gama e Cabeça de Veado. Universidade de Brasília, Departamento de Engenharia Florestal, Brasília, 59p.

Ferreira, C. P. \& L. Casatti. 2006. Influência da estrutura do hábitat sobre a ictiofauna de um riacho em uma micro-bacia de pastagem São Paulo, Brasil. Revista Brasileira de Zoologia, 23: 642-651.

Fialho, A. P., L. G. Oliveira, F. L. Tejerina-Garro \& L. C. Gomes. 2007. Fish assemblages structure in tributaries of the meia Ponte River, Goiás, Brasil. Neotropical Ichthyology, 5: 53-60.

Fitzgerald, D. G., E. Kott, R. P. Lanno \& D. G. Dixon. 1998. A quarter century of change in the fish communities of three small streams modified by anthropogenic activities. Journal of Aquatic Ecosystem Stress and Recovery, 6: 111-127.

Gorman, O. T. \& J. R. Karr. 1978. Habitat structure and stream fish communities. Ecology, 59: 507-515.

Gotelli, N. J. \& R. K. Colwell. 2001. Quantifying biodiversity: procedures and pitfalls in the measurement and comparison of species richness. Ecology Letters, 4: 379-391.

Hitt, N. P. \& P. L. Angermeier. 2008. Evidence for fish dispersal from spatial analysis of stream network topology. Journal of the North American Benthological Society, 27: 304-320.

Ibañez, C., J. Belliard, R. M. Hughes, P. Irz, A. Kamdem-Toham, N. Lamouroux, P. A. Tedesco \& P. Oberdorff. 2009. Convergence of temperate and tropical stream fish assemblages. Ecography, 32: 658-670.

Jones, E. B. D., G. S. Helfman, J. O. Harper \& P. V. Bolstad. 1999. Effects of riparian forest removal on fish assemblages in southern Appalachian streams. Conservation Ecology, 13: 1454-1465.

Köppen, W. 1948. Climatologia: con um estudio de los climas de la terra. México, Fondo de Cultura Econômica, 479p.

Langeani, F., L. Casatti, H. S. Gameiro, A. B. Carmo \& D. C. RossaFeres. 2005. Riffle and pool fish communities in a large stream of southeastern Brazil. Neotropical Ichthyology, 3: 305-311.

Langeani, F., R. M. C. Castro, O. T. Oyakawa, O. A. Shibatta, C. S. 
Pavanelli \& L. Casatti. 2007. Diversidade da ictiofauna do Alto Rio Paraná: composição atual e perspectivas futuras. Biota Neotropica, 7: 181-197.

Lee, S. M. \& A. Chao. 1994. Estimating population size via sample coverage for closed capture-recapture models. Biometrics, 50: $88-97$.

Legendre, P. \& L. Legendre. 1998. Numerical ecology. $2^{\text {nd }}$ english edition. Amsterdam, Elsevier Science B.V., 853p.

Lowe-McConnell, R. H. 1987. Ecological studies in tropical fish communities. Cambridge, Cambridge Univ. Press, 382p.

Lucinda, P. H. F. 2008. Systematics and biogeography of the genus Phalloceros Eigenmann, 1907 (Cyprinodontiformes: Poeciliidae: Poeciliinae), with the description of twenty-one new species. Neotropical Ichthyology, 6: 113-158.

Magurran, A. E. 2004. Measuring biological diversity. Oxford, Wiley-Blackwell, 256p.

Marrs, R. H. \& A. S. Watt. 2006. Biological Flora of the British Isles: Pteridium aquilinum (L.) Kuhn. Journal of Ecology, 94: 1272-1321.

Mistry, J. \& A. Berardi. 2005. Assessing fire potential in a Brazilian Savanna nature reserve. Biotropica, 37: 439-451.

Moyle, P. B. \& T. Light. 1996. Biological invasions of freshwater: empirical rules and assembly theory. Biological Conservation, 78: 149-161.

Myers, N., R. A. Mittermeier, C. G. Mittermeier, G. A. B. Fonseca \& J. Kent. 2000. Biodiversity hotspots for conservation priorities. Nature, 403: 853-858.

Peres-Neto, P. R. 2004. Patterns in the co-occurrence of fish species in streams: the role of site suitability, morphology and phylogeny versus species interactions. Oecologia, 140: 352-360.

Pivello, V. R., C. N. Shida \& S. T. Meirelles. 1999. Alien grasses in Brazilian savannas: a threat to the biodiversity. Biodiversity and Conservation, 8: 1281-1294.

Poff, N. L. 1997. Landscape filters and species traits: towards mechanistic understanding and prediction in stream ecology. Journal of the North American Benthological Society, 16: 391-409.

Pomeroy, R. \& H. D. Kirschman. 1945. Determination of dissolved oxygen - proposed modification of the Winkler method. Industrial and Engineering Chemistry-Analytical Edition, 17: 715-716.

Quinn, G. P. \& M. J. Keough. 2002. Experimental design and data analysis for biologists. Cambridge, Cambridge University Press, 537p.

R Development Core Team. 2010. R: A language and environmental for statistical computing. Vienna, R Foundation for Statistical Computing.

Reis, R. E., S. O. Kullander \& C. Ferraris. 2003. Check list of the freshwater fishes of South and Central America (CLOFFSCA). Porto Alegre, Edipucrs, 729p.

Ribeiro, J. F. \& B. M. T. Walter. 1998. Fitofisionomias do bioma Cerrado. Pp. 89-166. In: Sano, S. M. \& S. P. Almeida (Eds.). Cerrado: ambiente e flora. Planaltina, DF, Embrapa-CPAC, 556p.

Ribeiro, M. C. L. B. 1994. Conservação da integridade biótica das comunidades de peixes do Ribeirão do Gama: Área de Proteção Ambiental (APA) Gama - Cabeça de Veado Distrito Federal.
Unpublished Ph.D. Dissertation, Universidade Estadual Paulista "Júlio Mesquita Filho", Rio Claro, 176p.

Rincón, P. A. 1999. Uso do micro-hábitat em peixes de riachos: métodos e perspectivas. Pp. 23-90. In: Caramaschi, E. P., R. Mazzoni \& P. R. Peres-Neto (Eds.). Ecologia de peixes de riachos. Série Oecologia Brasiliensis, vol. VI. Rio de Janeiro, PPGE-UFRJ, 260p.

Schneider, M. 2008. Composição e estrutura trófica da comunidade de peixes de riachos da sub-bacia do ribeirão Bananal, Parque Nacional de Brasília, bioma Cerrado, DF. Unpublished M.Sc. Dissertation, Universidade de Brasília, Brasília, 62p.

Silveira, L. G. G., F. Langeani, W. J. Graça, C. S. Pavanelli \& P. A. Buckup. 2008. Characidium xanthopterum (Ostariophysi: Characiformes: Crenuchidae): a new species from the Central Brazilian Plateau. Neotropical Ichthyology, 6: 169-174.

Súarez, Y. R. 2008. Variação espacial e temporal na diversidade e composição de espécies de peixes em riachos da bacia do rio Ivinhema, Alto Rio Paraná. Biota Neotropica, 8: 197-204.

Súarez, Y. R. \& S. E. Lima-Júnior. 2009. Variação espacial e temporal nas assembléias de peixes de riachos na bacia do rio Guiraí, Alto Rio Paraná. Biota Neotropica, 9: 101-111.

Ter Braak, C. J. F. 1986. Canonical correspondence analysis: a new eigenvector technique for multivariate direct gradient analysis. Ecology, 67: 1167-1179.

Teresa, F. B. \& R. M. Romero. 2010. Influence of the riparian zone phytophysiognomies on the longitudinal distribution of fishes: evidence from a Brazilian savanna stream. Neotropical Ichthyology, 8: 163-170.

Uieda, V. S. \& R. M. C. Castro. 1999. Coleta e fixação de peixes de riacho. Pp. 01-22. In: Caramaschi, E. P., R. Mazzoni \& P. R. Peres-Neto (Eds.). Ecologia de peixes de riachos. Série Oecologia Brasiliensis, vol. VI. Rio de Janeiro, PPGE-UFRJ, 260p.

Valério, S. B., Y. R. Súarez, T. R. A. Felipe, K. K. Tondato \& L. Q. L. Ximenes. 2007. Organization patterns of headwater-stream fish communities in the Upper Paraguay-Paraná basins. Hydrobiologia, 583: 241-250.

Van Tongeren, O. F. R. 1995. Cluster analysis. Pp. 174-212. In: Jongman, R. H. G., C. J. F. Ter Braak \& O. F. R. Van Tongeren (Eds.). Data analysis in community and landscape ecology. Cambridge, Cambridge University Press, 299p.

Vannote, R. L., G. W. Minshall, K. W. Cummins, J. R. Sedell \& C. E. Cushing. 1980. The river continuum concept. Canadian Journal of Fisheries and Aquatic Sciences, 37: 130-137.

Vanzolini, P. E. \& N. Papavero. 1967. Manual de coleta e preparação de animais terrestres e de água doce. São Paulo, Secretaria de Agricultura, 223p.

Viana, J. P. 1989. Estrutura da comunidade dos peixes do Ribeirão Sant'ana (Brasília - DF) ao longo de gradientes ambientais. Unpublished M.Sc. Dissertation, Universidade de Brasília, Brasília, 115p.

Zawadzki, C. H., C. S. Pavanelli \& F. Langeani. 2008. Neoplecostomus (Teleostei: Loricariidae) from the upper Rio Paraná basin, Brazil, with description of three new species. Zootaxa, 1757: 31-48.

Accepted March 18, 2011 Published June 30, 2011

Appendix 1. Voucher specimens deposited in Coleção Ictiológica da Universidade de Brasília (CIUnB): Astyanax sp. CIUnB 474-492; Bryconamericus stramineus CIUnB 450; Characidium sp. CIUnB 468, 469; Characidium xamthopterum CIUnB 470, 471; Characidium zebra CIUnB 472, 473; Gymnotus carapo CIUnB 439; Hasemania sp. CIUnB 456-462; Hoplias malabaricus CIUnB 467; Hypostomus ancistroides CIUnB 435; Hypostomus sp.1 CIUnB 434; Hypostomus sp. 2 CIUnB 428-433; Hypostomus sp.3 CIUnB 425; Hypostomus sp.4 CIUnB 436; Knodus moenkhausii CIUnB 493-504; Microlepidogaster longicolla CIUnB 437; Moenkhausia sp. CIUnB 451-453; Neoplecostomus corumba CIUnB 438; Phalloceros harpagos CIUnB 442-447; Piabina argentea CIUnB 454, 455; Planaltina myersi CIUnB 463-466; Poecilia reticulata CIUnB 448, 449; Rivulus pictus CIUnB 440, 441. 